\title{
UJI AKTIFITAS ANTIBAKTERI EKSTRAK DAUN SIRSAK (Annona muricata) TERHADAP \\ BAKTERI Staphylococcus aureus SECARA IN VITRO
}

\author{
Irmawati* \\ *Jurusan Biologi Fakultas Sains dan Teknologi \\ Universitas Islam Negeri (UIN) Alauddin Makassar \\ email: irmawatibiologi85@gmail.com
}

\begin{abstract}
Abstrak: Daun sirsak (Annona muricata L) dikenal memiliki zat anti-kanker yang dapat membunuh sel-sel kanker tanpa mengganggu sel-sel sehat dalam tubuh manusia yang disebut acetogenins. Acetogenins adalah senyawa polyketides dengan struktur 30-32 rantai karbon tidak bercabang yang terikat pada gugus 5-methyl-2-furanone. Tujuan penelitian ini adalah untuk mengetahui daya antibakteri ekstrak daun sirsak terhadap bakteri Staphylococcus aureus secara in vitro. Sebelum dilakukan uji antibakteri, sampel yang telah diekstrak secara maserasi diuji fitokimia terlebih dahulu untuk menentukan kandungan metabolit sekunder yang telah diketahui berperan sebagai agen antibakteri. Lalu dilakukan uji fitokimia, ekstrak diuji aktivitas antibakterinya terhadap bakteri Staphylococcus aureus dengan menggunakan teknik difusi agar dengan cara sumuran. Kemudian ekstrak dilarutkan pada aquades disteril dengan perbandingan $2 \mathrm{~g}$ ekstrak pada $2 \mathrm{~mL}$ air. Untuk kontrol positif, digunakan ciprofloxacin dan aquades steril sebagai kontrol negatif. Oleh karena itu daun sirsak memilki kandungan yang berpotensi untuk membunuh atau menghambat pertumbuhan bakteri Staphylococcus aureus.
\end{abstract}

Kata Kunci: Annona muricata, Antibakteri, Staphylococcus aureus

\section{PENDAHULUAN}

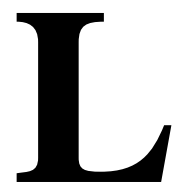

ingkungan yang tidak sehat adalah salah satu faktor penyebab penyakit infeksi. Penyakit infeksi disebabkan oleh bakteri, virus, fungi dan parasit. Misalnya bakteri Staphylococcus aureus merupakan bakteri patogen penyebab infeksi. Staphylococcus aureus dapat menyebabkan infeksi pada tulang, sendi dan infeksi nosokomial. Oleh karena itu dalakukan 
untuk membunuh atau menghambat pertumbuhan bakteri biasanya digunakan suatu formula yang mengandung zat untuk menghambat pertumbuhan bakteri tersebut, atau bahkan membunuhnya. Zat ini umum dikenal sebagai antibakteri dan dalam dunia medis lebih dikenal dengan antibiotik.

Selama ini, antibiotik merupakan produk dalam pengobatan dan penanggulangan infeksi pada pelayanan kesehatan. Berbagai jenis antibiotik yang digunakan dalam pengobatan infeksi yang semakin banyak dapat meningkatkan terjadinya resistensi terhadap berbagai antibiotik yang beredar (Ratna, 2015).

Obat-obatan yang biasa digunakan untuk terapi penyakit infeksi biasanya berupa obat modern atau obat tradisional. Akan tetapi, obat modern tersebut berisiko tinggi timbulnya efek samping yang tidak diinginkan, bahkan tak jarang dapat menimbulkan resistensi bakteri. Oleh karena itu, penggunaan obat-obatan tradisional dapat digunakan sebagai alternatif pengobatan sehingga penggunaan obat tradisional menjadi semakin meningkat dan berkembang luas di masyarakat (Sari, 2010).

Negara Indonesia merupakan negeri yang kaya akan keanekaragaman hayati yang dimiliki oleh hewan dan tumbuhannya. Khusus untuk tumbuhan. Dimana tumbuhan memilki berbagai jenis spesies yang dapat dimanfaatkan sebagai obat maupun bahan makanan, contonnya daun sirsak yang dapat manfaatkan sebagai obat anti kanker, diabetes militus, diare dan sebagainya (Ngajow, 2013).

Daun sirsak (Annona muricata L) memiliki kandungan kimia berupa alkaloid, tannin, dan beberapa kandungan lainnya termasuk senyawa annonaceous acetogenins. Annonaceous acetogenins merupakan senyawa yang memiliki potensi sitotoksik. Senyawa sitotoksik merupakan senyawa yang dapat bersifat toksik untuk menghambat dan menghentikan pertumbuhan sel kanker.

Kandungan senyawa dalam daun sirsak (Annona muricata L) antara lain steroid atau terpenoid, flavonoid, kumarin, alkaloid, dan tanin. Senyawa flavonoid berfungsi sebagai antioksidan untuk penyakit kanker, anti mikroba, antivirus, pengatur fotosintetis, dan pengatur tumbuh (Puspitasari, 2016). 
Di sisi lain daun sirsak (Annona muricata L) dikenal memiliki zat antikanker yang dapat membunuh sel-sel kanker tanpa mengganggu sel-sel sehat dalam tubuh manusia yang disebut acetogenins. Acetogenins adalah senyawa polyketides dengan struktur 30-32 rantai karbon tidak bercabang yang terikat pada gugus 5-methyl-2- furanone. Salah satu gugus dari acetogenin adalah fenol sehingga menyebabkan kandungan total fenol yang terdapat pada daun sirsak tergolong tinggi. Ekstrak etanol daun sirsak ditemukan asam fenolat dalam bentuk bebas, bentuk glikosida, dan bentuk ester adalah asam kafeat, asam p-kumarat, asam phidroksibenzoat, dan asam vanilat. Sedangkan asam ferulat hanya ada dalam bentuk glikosida dan ester. Flavonoid yang ditemukan diduga kaemferol. Hasil identifikasi golongan flavonoid menunjukkan ekstrak daun sirsak mengandung flavonoid golongan flavon, dihidroflavonol, flavonol, dan flavanon (Puspitasari, 2016).

Daun sirsak (Annona muricata L) dimanfaatkan sebagai pengobatan alternatif untuk pengobatan kanker, yakni dengan mengkonsumsi air rebusan daun sirsak. Selain untuk pengobatan kanker, tanaman sirsak juga dimanfaatkan untuk pengobatan demam, diare, antikejang, anti jamur, anti parasit, antimikroba, sakit pinggang, asam urat, gatal-gatal, bisul, flu, dan sebagainya. Daun sirsak (Annona muricata L) berpotensi sebagai antihipertensi, antispasmodik, obat pereda nyeri, hipoglikemik, antikanker, emetik (menyebabkan muntah), vermifuge (pembasmi cacing). Daun sirsak (Annona muricata L) juga memiliki efek yang bermanfaat dalam meningkatkan aktivitas enzim antioksidan dan hormon insulin pada jaringan pankreas serta melindungi dan menjaga selsel $\beta$-pankreas (Puspitasari, 2016).

Pada daun sirsak (Annona muricata L) ditemukan senyawa acetogenin yang bermanfaat mengobati berbagai penyakit. Acetogenin berperan serta dalam melindungi sistem kekebalan tubuh serta mencegah infeksi yang mematikan. Daun sirsak mengandung acetogenin yang mampu melawan 12 jenis sel kanker. Banyaknya manfaat sirsak membuat orang mulai beralih mengonsumsi suplemen herbal daun sirsak sebagai alternatif pencegahan dan pengobatan konvensional. Pada daun sirsak, telah ditemukan 18 jenis annonaceous acetogenin dan telah 
terbukti secara in vitro bersifat sitotoksik. Daun sirsak (Annona muricata L) memiliki sifat toksik yang tinggi terhadap sel kanker ovarium, serviks, dan sel kanker kulit pada dosis rendah. Acetogenins sering disebut sebagai inhibitor I atau penghambat pertumbuhan sel kanker paling kuat (Puspitasari, 2016).

Berdasarkan latar belakang di atas, maka dilakukan penelitian tentang uji aktivitas antibakteri daun sirsak (Annona muricata L) terhadapa bakteri Staphylococcus aureus secara in vitro.

\section{METODE PENELITIAN}

\section{Preparasi sampel}

Sampel utama dari penelitian ini adalah daun sirsak (Annona muricata L) yang diambil dari perkebunan warga Desa Kappuna Kecamatan Masamba. lalu dibersihkan dan dikeringanginkan selama 3 hari, kemudian digiling menjadi serbuk dan diayak dengan ukuran 65 mesh.

\section{Ekstraksi}

Pada daun sirsak yang telah menjadi serbuk diambil $50 \mathrm{~g}$ kemudian dimaserasi 2 kali dengan $500 \mathrm{~mL}$ etanol 95\% selama 6 x 24 jam, kemudian disaring dengan kertas saring dan dievaporasi dengan rotary evaporator. Setelah itu, sample dimasukkan ke dalam oven selama 1 x 24 jam pada $102^{\circ} \mathrm{C}$, kemudian disimpan dalam desikator. Setelah itu dihitung rendemen ekstrakdengan menggunakan rumus:

$$
\frac{\text { Berat Ekstrak }}{\text { Berat Sampel }} \text { X } 100
$$

\section{Analisis Fitokimia (Harborne, 1987)}

\section{Analisis senyawa alkaloid}

Sebanyak 2 g sampel tumbuhan yang telah dihaluskan ditambahkan kloroform secukupnya lalu dihaluskan lagi. Kemudian ditambah $10 \mathrm{ml}$ amoniak dan $10 \mathrm{ml}$ kloroform. Larutan disaring ke dalam tabung reaksi, dan difiltrat ditambahkan asam sulfat $2 \mathrm{~N}$ sebanyak 10 tetes. Filtrat dikocok dengan teratur 
kemudian dibiarkan beberapa lama sampai terbentuk dualapisan. Lapisan atas dipindahkan ke dalam tiga tabung reaksi masing- masing 2,5 ml. Ketiga larutan ini dianalisis dengan pereaksi Dragendorff. Terbentuknya endapan jingga dengan pereaksi Dragendorff menunjukkan hasil positif.

\section{Analisis senyawa triterpenoid dan steroid}

Sebanyak 2 g sampel tumbuhan yang telah dihaluskan, ditempatkan pada plat tetes dan ditambahkan asam asetat anhidrat sampai sampel terendam semuanya, dibiarkan selama kira-kira15 menit, enam tetes larutan dipindahkan ke dalam tabung reaksi dan ditambah 2-3 tetes asam sulfat pekat. Adanya triterpenoid ditunjukkan dengan terjadinya warna merah, jingga atau ungu, sedangkan adanya steroid ditunjukkan dengan adanya warnabiru.

\section{Analisis senyawa flavanoid}

Sebanyak 2 g sampel tumbuhan yang telah diekstrak dengan $5 \mathrm{ml}$ etanol, dipanaskan selama lima menit di dalam tabung reaksi. Selanjutnya ditambah beberapa tetes $\mathrm{HCl}$ pekat. Kemudian ditambahkan 0,2 g bubuk Mg. Hasil positif ditunjukkan dengan timbulnya warna merah tua dalam waktu 3 menit.

\section{Analisis senyawa saponin}

Sebanyak 2 g sampel tumbuhan yang telah dihaluskan dimasukkan ke dalam tabung reaksi, ditambah air suling sehingga seluruh cuplikan terendam, dididihkan selama 2-3 menit, dan selanjutnya didinginkan, kemudian dikocok kuatkuat. Hasil positif ditunjukkan dengan terbentuknya buih yang stabil.

\section{Analisis senyawa tanin}

Sebanyak 2 g sampel tumbuhan yang telah dihaluskan, ditambah etanol sampai sampel terendam semuanya. Kemudian sebanyak $1 \mathrm{ml}$ larutan dipindahkan kedalam tabung reaksi dan ditambahkan 2-3 tetes larutan $\mathrm{FeCl} 31 \%$. Hasil positif ditunjukkan dengan terbentuknya warna hitam kebiruan atau hijau.

\section{Uji Aktivitas Antibakteri}

Untuk metode uji antibakteri diadaptasi dari metode Lay (1994) dengan menggunakan teknik Sumuran (Difusi Agar) yang telah dimodifikasi. Pertamatama, alat-alat non gelas disterilkan terlebih dahulu di dalam autoklaf pada suhu 
$121^{\circ} \mathrm{C}$ selama 15 menit dan alat-alat gelas disterilkan di oven suhu $160-170^{\circ} \mathrm{C}$ selama 2 jam. Jarum ose dibakar dengan api bunsen.

\section{Pembuatan Media}

\section{Media Agar Miring}

Diambil Nutrient Agar (NA) sebanyak 0,46 g dilarutkan dalam $20 \mathrm{~mL}$ aquades (23 g/1000 mL) menggunakan erlenmeyer. Selanjutnya dihomogenkan dengan stirrer di atas penangas air sampai mendidih. Sebanyak $5 \mathrm{~mL}$ dituangkan masing- masing pada 3 tabung reaksi steril dan ditutup dengan aluminium foil. Media disterilkan dalam autoklaf dengan suhu $121^{\circ} \mathrm{C}$ selama 15 menit, kemudian dibiarkan pada suhu ruangan selama \pm 30 menit sampai media memadat pada kemiringan $30^{\circ}$. Media agar miring digunakan untuk inokulum bakteri.

\section{Media Dasar dan Media Pertumbuhan}

Media dasar dibuat dengan cara ditimbang Nutrient Agar (NA) sebanyak 2,3 gram, lalu dilarutkan dalam $100 \mathrm{~mL}$ aquades $(23 \mathrm{~g} / 1000 \mathrm{~mL})$ menggunakan Erlenmeyer. Sedangkan media pembenihan dibuat dengan cara ditimbang 4,6 g $\mathrm{NA}$, lalu dilarutkan dalam $100 \mathrm{~mL}$ aquades (46 g/1000 mL) menggunakan Erlenmeyer. Setelah itu, masing-masing media dihomogenkan dengan stirer diatas penangas air sampai mendidih. Media-media yang dihomogenkan dan disterilkan dalam autoklaf pada suhu $121^{\circ} \mathrm{C}$ selama 15 menit, kemudian didinginkan sampai suhu $\pm 45-50^{\circ} \mathrm{C}$. Media dasar dan media pembenihan digunakan dalam pembuatan media pengujian sebagai lapisan dasar dan lapisan kedua.

\section{Pembuatan Standar Kekeruhan Larutan (Larutan Mc. Farland)}

Larutan asam sulfat 0,36 $\mathrm{N}$ sebanyak 99,5 $\mathrm{mL}$ dicampurkan dengan larutan $\mathrm{BaCl} 2.2 \mathrm{H} 2 \mathrm{O}$ 1,175 \% sebanyak 0,5 mL dalam Erlenmeyer kemudian dikocok sampai terbentuk larutan yang keruh. Kekeruhan ini dipakai sebagai standar kekeruhan suspensi bakteri uji. 


\section{Pembuatan Suspensi Bakteri Uji}

Bakteri uji pada media agar miring diambil dengan kawat ose steril lalu disuspensikan ke dalam tabung yang berisi $2 \mathrm{~mL}$ larutan $\mathrm{NaCl} 0,9 \%$ hingga diperoleh kekeruhan yang sama dengan standar kekeruhan larutan Mc. Farland.

\section{Pembuatan Media Pengujian}

Lapisan dasar dibuat dengan menuangkan masing-masing $10 \mathrm{~mL}$ NA ke dalam 3 cawan petri, kemudian dibiarkan memadat. Setelah memadat, permukaan lapisan dasar ditanam 5 pencadang baja yang diatur jaraknya agar daerah pengamatan tidak bertumpu. Suspensi bakteri dicampurkan ke dalam media pembenihan NA. Selanjutnya dituangkan $25 \mathrm{~mL}$ NA pada tiap cawan petri yang diletakkan pencadang sebagai lapisan kedua.Setelah lapisan kedua memadat, pecadang diangkat menggunakan pinset dari masing-masing cawan petri, sehingga terbentuk sumur-sumur yang akan digunakan dalam uji bakteri.

\section{Penentuan Aktivitas Antibakteri}

Kegiatan ini dibuat untuk mengetahui aktivitas antibakteri ekstrak etanol kulit batang matoa yang dilakukan dengan metode difusi agar, dengan cara mengukur diameter hambatan pertumbuhan bakteri terhadap bakteri Staphylococcus aureus. Cara penentuannya adalah sebagai berikut: sumuran yang sudah dibuat pada media pengujian diteteskan larutan uji yaitu ekstrak yang dilarutkan dalam aquades steril sebanyak 2 gr dalam $2 \mathrm{~mL}$ aquades sebanyak $50 \mu \mathrm{l}$ menggunakan mikropipet, kemudian diinkubasi dalam inkubator pada suhu $37^{\circ} \mathrm{C}$ selama 24 jam, setelah itu dilihat ada tidaknya zona hambat yang terbentuk. Jika ada, diukur diameter daerah hambatan di sekitar pencadang menggunakan jangka sorong dengan cara mengukur secara horizontal dan vertikal kemudian hasil yang didapat dikurangi diameter sumuran $7 \mathrm{~mm}$.

\section{DAFTAR PUSTAKA}

Ngajowa M, dkk. "Pengaruh Antibakteri Ekstrak Kulit Batang Matoa (Pometia pinnata) terhadap Bakteri Staphylococcus aureus secara In vitro". Jurnal Mipa Unsrat. Vol 2 No 2. (November, 2013). 
Puspitasar M, L, dkk. "Aktivitas Antioksidan Suplemen Herbal Daun Sirsak (Annona muricata L.) Dan Kulit Manggis (Garcinia mangostana L.): Kajian Pustaka". JurnalPangan dan Agroindustri Vol 4 No 1. (Januari, 2016).

Ratna Y, R, dkk. "Daya Antibakteri Ekstrak dan Fraksi-Fraksi Daun Jambu Mete (Anacardium occidentale L.) terhadap Bakteri Staphylococcus aureus Sensitif dan Multiresisten". Jurnal Ilmu Kefarmasian Indonesia. Vol 4 No 1. (April, 2016).

Sari Y, D, dkk. "Uji Aktivitas Antibakteri Infusa Daun Sirsak (Annona muricata L.) Secara In Vitro Terhadap Staphylococcus aureus Atcc 25923 Dan Escherichia coli Atcc 35218 Serta Profil Kromatografi Lapis Tipisnya". Jurnal KES MAS Vol 4 No 3. (September, 2010). 